\section{Informação e objeto etnográfico: percurso interdisciplinar no Museu Paraense Emílio Goeldi}

\author{
Alegria Benchimol \\ abenchimol@museu-goeldi.br \\ Dissertação de Mestrado \\ Programa de Pós-Graduação em Ciência da Informação \\ Universidade Federal Fluminense / Instituto Brasileiro de \\ Informação em Ciência e Tecnologia \\ Rio de Janeiro (RJ) 2009
}

\section{Information and ethnographic object: interdisciplinary course at the Goeldi Museum}

\author{
Alegria Benchimol \\ abenchimol@museu-goeldi.br \\ Master Dissertation \\ Pos-Graduation Program in Information Science \\ Fluminense Federal University / Brazilian Institute for \\ Information in Science and Technology \\ Rio de Janeiro (RJ) - Brazil 2009
}

Estudo teórico, cujo objetivo é elaborar o ciclo da informação do objeto etnográfico da coleção do Museu Paraense Emílio Goeldi (MPEG), situado no Pará (Brasil), a partir dos conceitos de 'documento' e 'informação', numa visão interdisciplinar do processo de transferência e de disseminação da informação. Consiste, assim, na busca pela compreensão da organização da coleção etnográfica do MPEG em três momentos distintos de sua história, tendo como resultado a elaboração de um quadro-matriz, no qual estão identificadas, reunidas e sistematizadas as informações registradas nos três períodos estudados (Nimuendajú, Galvão e Velthem). A análise é finalizada pela construção de um modelo de ciclo de informação do MPEG, que indica seis etapas para o processo informacional e comunicacional do objeto etnográfico, refletindo, nesse percurso, sua trajetória interdisciplinar.
Theoretical approach aiming to analyze the informational cycle of the ethnographic object in the collection of Emilio Goeldi Museum of Pará, in Brazil, from an interdisciplinary point of view of the process of transference and dissemination of information. The study seeks to understand the attributes of the terms 'document' and 'information' within a conceptual net, revealing the organization of the ethnographic collection in three different periods of the Museum history (during the terms of Nimuendajú, Galvão and Velthem), all identified by a chart in a systematic way. The analysis is concluded with the construction of a model of information cycle for Goeldi Museum, which indicates six stages for the informational and communicational process of the ethnographic object reflecting, in its way, an interdisciplinary trajectory. 